\title{
EKSISTENSI BALAI HARTA PENINGGALAN DALAM PENANGANAN KASUS KEWARISAN ANAK
}

\author{
NURHIDAYAH A. HAMBALI, SUBEHAN KHALIK \\ Fakultas Syariah dan Hukum Universitas Islam Negeri Alauddin Makassar
}

\begin{abstract}
Abstrak
Balai Harta Peninggalan dalam penanganan kasus kewarisan anak telah mematuhi hukum yang ada dan sudah sesuai dengan standar Kompilasi Hukum Islam (KHI). Ini menunjukkan bahwa para wali harus lebih memperhatikan tugasnya sebagai wali anak agar mengelola warisan si anak dengan baik dan tidak menyalahgunakan harta anak dibawah perwaliannya agar harta warisan anak tetap terlindungi dan wali anak berkewajiban untuk mengasuh anak yang berada dibawah perwaliannya. Dengan adanya harta peninggalan yang tidak terurus maka dari itu Balai harta peninggalan harus lebih meningkatkan pengawasan sebagai wali anak dan meningkatkan kinerjanya baik dari sumber daya manusia, agar tidak terjadi kesalahan dengan mengikuti cara pelaksanaan penanganan pembagian hak anak dalam kewarisan.

Kata Kunci : Anak, Balai Harta Peninggalan, Kewarisan.
\end{abstract}

\begin{abstract}
The Probate Court in handling cases of inheritance of children has complied with existing laws and is in accordance with islamic law compilation standards. This shows that guardians must pay more attention to their duties as guardians of children in order to manage the child's inheritance well and not to abuse the assets of the child under his guardianship so that the child's inheritance remains protected and the child's guardian is obliged to care for the child under his guardianship. With the inheritance of assets that aren't taken care, the inheritance hall should increase supervision as a guardian of children and improve their performance both from human resources, so that mistakes don't occur by following the implementation of handling the distribution of children's rights in inheritance.
\end{abstract}

Keywords: Children, Heritage Sites, Inheritance. 


\section{A. PENDAHULUAN}

Indonesia adalah negara yang berdasarkan hukum sebagaimana diatur dalam pasal 1 ayat 3 UUD 1945. Hukum seringkali dipahami oleh masyarakat sebagai suatu perangkat aturan yang dibuat oleh negara dan mengikat warga negaranya dengan mekanisme keberadaan sanksi sebagai pemaksa untuk menegakkan hukumnya. ${ }^{1}$

Selain bersifat memaksa, dalam hukum perdata pada umumnya hukum bersifat mengatur. Adapun untuk mencapai tujuan hukum itu, hukum harus difungsikan dan dilaksanakan dalam berbagai aspek kehidupan, baik dalam lingkungan keluarga maupun dalam masyarakat.

Hukum kewarisan adalah salah satu bagian dari hukum perdata secara keseluruhan dan merupakan bagian kecil dari hukum keluarga, maka hukum kewarisan adalah bagian dari hukum kekeluargaan yang memegang peranan sangat penting, bahkan menentukan dan mencerminkan sistem dan bentuk hukum yang berlaku dalam masyarakat. ${ }^{2}$

Setelah datangnya Islam, hukum kewarisan yang berpihak kepada golongan tertentu mengalami revisi. Diantara penertiban yang dimaksud adalah aturan yang memberikan hak kewarisan kepada kaum wanita. Tidak hanya itu, aturan yang dimaksud dengan rinci memberikan hak-hak kewarisan dari pihak keluarga dalam garis keturunan ayah, maupun ibu. $^{3}$

Hukum waris adalah hukum yang mengatur kedudukan harta kekayaan seseorang setelah ia meninggal, terutama berpindahnya harta kekayaan itu kepada orang lain. ${ }^{4}$ Dalam hal kewarisan anak yang walinya lalai dalam pengurusan harta kewarisan anak maka diberikan kepada Balai Harta Peninggalan. Sebagaimana diatur dalam pasal 338 KUHPerdata yang menyatakan bahwa "Bila dalam tenggang waktu yang ditentukan untuk itu, wali lalai menaruh ikatan jaminan atau gadai dan tidak memiliki harta benda tak bergerak yang cukup, maka atas tuntutan Balai Harta Peninggalan, pengurusan harta kekayaan anak belum dewasa harus dicabut oleh Pengadilan Negeri dan diberikan kepada Balai Harta Peninggalan, sampai wali memberikan jaminan secukupnya; yaitu bila atas permintaan wali, pengadilan negeri setelah mendengar Balai Harta Peninggalan, menyerahkan tugas tersebut kembali kepada wali.

Balai Harta Peninggalan bergerak dalam bidang harta peninggalan dan kepailitan. Terhadap perwalian atas anak-anak dibawah umur BHP berfungsi sebagai wali pengawas jika telah diangkat seorang wali oleg Pengadilan. Wali disini harus melakukan kewajiban-kewajibannya sesuai dengan peraturan perundang-undangan. Namun banyak terjadi penyalahgunaan wewenang yang dilakukan wali terhadap harta kelayaan anak dibawah umur, sehingga menimbulkan kerugian, upaya yang harus dilakukan oleh BHP dalam mencegah penyalahgunaan wewenang Pengadilan ialah, melakukan sumpah dan dibuat berita acara sumpah yang diberikan kepada BHP sehingga dapat diketahui adanya penetapan perwalian yang dilakukan Pengadilan. Hal ini untuk menghindari hak-hak yang dapat hilang yang dimiliki anak terutama dalam kepemilikan harta yang diberi dari 2013), h. 6

${ }^{1}$ Teguh Prasetyo, Kriminalisasi Dalam Hukum Pidana, (Cet. III; Bandung: Penerbit Nusa Media,

${ }^{2}$ Syamsulbahri Salihima, Perkembangan Pemikiran Pembagian Warisan Dalam Hukum Islam Dan Implementasinya Pada Pengadilan Agama, (Jakarta: Prenadamedia Group, 2015), h. 1-2.

${ }^{3}$ Subehan Khalik, Wasiat Kepada Ahli Waris "Telaah Fikih Dengan Pendekatan Kritik Kesahihan Hadis”, (Makassar: Alauddin University Press, 2013), h. 2.

${ }^{4}$ Titik Triwulan Tuti, Pengantar Hukum Perdata di Indonesia, (Cet. I; Jakarta: Prestasi Pustaka, 2006), h. 275. 
orang tua yang meninggal dunia. Maka wali tidak dapat melakukan hal-hal yang merugikan karena BHP yang mengawasi kewajiban yang harus dilakukan wali. Hal tersebut diatur dalam KUHPerdata. Hambatan yang terjadi SDM yang minim, sarana dan prasarana kerja, tidak adanya sanksi jika terjadi suatu pelanggaran yang dilakukan wali. Menyikapi masalah yang terjadi diatas maka perlu dibenahi peraturan perundangundangan serta birokrasi terkait yang sesuai dengan masyarakat dan tujuan awal yaitu pelayanan hukum. Sehingga dapat tercapai kinerja yang optimal yang sebagaimana mestinya agar masyarakat mengetahui eksistensi BHP dalam pelayanan hukum.

Balai Harta Peninggalan bertugas untuk mengawasi pembagian harta anak. Sebagaimana diatur dalam pasal 366 KUHPerdata "Dalam setiap perwalian yang diperintahkan di Indonesia, Balai Harta Peninggalan ditugaskan sebagai wali pengawas"

Balai Harta Peninggalan diharapkan berperan dalam memeberikan pelayanan secara optimal sehingga sesuai dengan adanya tuntutan reformasi dan demokratisasi sejak tahun 1997 yang memasyarakatkan perubahan paradigm kepemerintahan, pembaharuan system kelembagaan dan peningkatan kompetensi sumber daya manusia dalam penyelenggaraan pemerintah dan pembangunan yang mengacu pada terselenggaranya pemerintah yang baik yaitu mewujudkan pemerintah yang bersih dan beribawa serta transparan (good governance). Selanjutnya masih terdapat hambatan-hambatan yang menyebabkan kurang optimalnya pelaksaaan tugas Balai Harta Peninggalan di masyarakat, yaitu hambatan-hambatan dalam hal Sumber Daya Manusia (SDM).

Orang yang berhak menerima harta warisan dapat dibedakan menjadi dua macam yaitu, ditentukan oleh undang-undang dan wasiat. Pewaris adalah orang yang meninggal dunia dengan meninggalkan harta kekayaan yang sebagiannya akan diwariskan kepada ahli waris. ${ }^{5}$ Sedangkan ahli waris adalah orang-orang yang akan menerima harta warisan yang ditinggalkan oleh pewaris. Sebagaimana diuraikan sebelumnya bahwa ahli waris penerima harta warisan setelah harta kekayaan orang diseleksi terlebih dahulu. Ahli waris menjadi salah satu syarat terjadinya kewarisan. Kalau ada pewaris yang menjadi syarat adalah kematian seseorang maka pada ahli waris sebaliknya yaitu harus benarbenar hidup disaat kematian pewaris. Selain itu seseorang dapat menjadi ahli waris kalau tidak ada faktor-faktor penghalang untuk mewarisi. ${ }^{6}$

Kewarisan maupun pewasiatan senantiasa berupaya untuk menumbuhkan semangat sosial secara kolektif. Orang yang akan memberikan wasiat di syaratkan memiliki kemampuan. Di samping itu, di syaratkan pula adanya keinginan secara ikhlas dari pewasiat untuk mewasiatkan sesuatu. Pewasiat haruslah merdeka dari unsur paksaan dalam bentuk apapun. ${ }^{7}$

Adapun klasifikasi ahli waris dapat dibagi menjadi beberapa macam yaitu: ahli waris yang mendapat bagian tertentu dalam keadaan tertentu meliputi (anak perempuan tunggal, ibu, bapak, duda, janda, saudara laki-laki, saudari bersyirkah, cucu perempuan dari putra, kakek, nenek, saudari seayah), ahli waris yang tidak ditentukan bagiannya meliputi (anak laki-laki, cucu laki-laki dari putra, bapak, kakek dari pihak bapak, saudara seibu, saudara sebapak, putra saudara sekandung, putra saudara sebapak, paman yang

${ }^{5}$ Abdul Ghofur Anshori, Hukum Kewarisan Islam di Indonesia, (Cet. I; Yogyakarta: Gadjah Mada University press, 2012), h. 29.

${ }^{6}$ Abdul Ghofur Anshori, Hukum Kewarisan Islam di Indonesia, h. 215.

${ }^{7}$ Subehan Khalik, Wasiat Kepada Ahli Waris "Telaah Fikih Dengan Pendekatan Kritik Kesahihan Hadis”, h. 19. 
sekandung dengan bapak, paman sebapak dengan bapak, putra paman yang sekandung bapak, putra bapak yang sebapak dengan bapak). ${ }^{8}$

Pewarisan menurut undang-undang ialah pembagian warisan kepada orang-orang yang ditunjuk langsung oleh undang-undang, baik karena mempunyai hubungan darah yang terdekat dengan pewaris (baik sah maupun di luar kawin yang diakui) maupun karena terjadinya perkawinan dengan si pewaris. ${ }^{9}$

Hal ini terterah dalam pasal 832 KUHPerdata:

Menurut undang-undang, yang berhak menjadi ahli waris ialah keluarga sedarah, baik yang sah menurut undang-undang maupun yang di luar perkawinan dan si suami atau si istri yang hidup terlama, menurut peraturan-peraturan berikut ini.

Bila keluarga sedarah dan si suami atau si istri yang hidup terlama tidak ada, maka semua harta peninggalan menjadi milik negara, yang wajib melunasi utang-utang orang yang meninggal tersebut, sejauh harga harta peninggalan mencukupi untuk itu. ${ }^{10}$

Yang dimaksud dengan keluarga sedarah dalam pasal tersebut ialah anak-anak dan atau keturunannya ialah anak itu sendiri dan atau beserta keturunanya dalam garis lencang kebawah, dengan tidak membedakan laki-laki atau perempuan dan dengan tidak membedakan urutan kelahiran. Mereka itu mengecualikan lain-lain anggota keluarga dalam garis lencang ke atas dan garis samping, meskipun mungkin di antara anggotaanggota keluarga yang belakangan ini, ada yang derajatnya lebih dekat dengan si meninggal. $^{11}$

Selain itu, ada pula yang dimaksud dengan mawani' al-irsi ialah penghalang terlaksananya waris-mewarisi. Artinya, seorang yang berhak mendapat harta warisan tetapi oleh karena padanya ada suatu keadaan tertentu, menyebabkan dia tidak mendapatkan warisan. Jadi, adanya dianggap tidak ada artinya sekali pun ia memenuhi syarat sebagai ahli waris tetapi karena ada sesuatu keadaan tertentu itu, terhalang ia memperoleh harta warisan. ${ }^{12}$

\section{B. METODE PENELITIAN}

Jenis penelitian ini kualitatif lapangan dengan pendekatan yang digunakan adalah: yuridis, normatif syar'i. Adapun sumber data penelitian ini adalah sumber data primer dengan cara turun langsung ke lapangan dan data sekunder melalui studi kepustakaan. Selanjutnya metode pengumpulan data yang digunakan adalah observasi dan penelitian kepustakaan. Lalu teknik pengolahan data dan analisis data dilakukan dengan tahap, yaitu: klasifikasi data, reduksi data, editing data, dan penarikan kesimpulan.

\section{PEMBAHASAN}

\section{Peranan Balai Harta Peninggalan Dalam Melakukan Pengawasan Wali dan Harta Anak}

Perwalian terjadi jika kekuasaan orang tua terhenti, baik karena salah satu atau keduanya telah meninggal dunia, karena adanya perceraian antara orang tuanya, karena dicabut kekuasaannya sebagai orang tua atau karena adanya yang dilahirkan tidak dalam perkawinan yang sah. Tujuan perwalian ini terutama agar harta si anak ada yang

\footnotetext{
${ }^{8}$ Abdul Ghofur Anshori, Hukum Kewarisan Islam di Indonesia, h. 48-50.

${ }^{9}$ Istiqamah, Hukum Waris dan Benda, (Makassar: Alauddin University Press, 2012), h. 25.

${ }^{10}$ Republik Indonesia, KUHPerdata, Bab X, Pasal 832.

${ }^{11}$ Istiqamah, Hukum Waris dan Benda, h. 26.

${ }^{12}$ Asymuni A. Rahman Dkk, Ilmu Fiqh, (Cet. II; Jakarta: Direktorat Jenderal Pembinaan
} Kelembagaan Agama Islam, 1986), h. 20. 
mengurus baik pribadinya maupun harta kekayaan yang ditinggalkan si mati untuk anaknya. Tugas untuk mengawasi perwalian menurut KUHPerdata Pasal 366 dapat dilimpahkan kepada Balai Harta Peninggalan dan tanggung jawab BHP sebagai wali pengawas adalah mengawasi wali dalam mengurus harta kekayaan anak dibawah umur. Seperti kasus yang terjadi: bahwa seorang wali yang tidak lain pamannya sendiri, Mustafa Lasulika (kakak dari almarhum ayahnya) nekat menjual harta warisan si anak Novry Satryo Nugroho Lasulika yaitu sebidang tanah seluas 88 M2 yang terletak di jalan Perintis Kemerdekaan, Kec. Tamalanrea, Kel. Tamalanrea Indah dan salah satu keluarga dari Ibunya (Merry Trivita Sutarto) yaitu Bibi (kakak dari almarhuma ibunya), Bibi tersebut keberatan karena mengetahui bahwa wali dari keponakannya itu telah menjual salah satu warisan milik keponakannya yang bukan diperuntuhkan untuk kebutuhan si anak dan bibi dari si anak melaporkan ke Balai Harta Peninggalan, putusan akhirnya dimenangkan oleh Bibi dari si anak itu dan Pengadilan Agama Makassar menunjuk BHP Makassar sebagai wali sementara sebelum ditetapkanya wali bagi si anak, harta yang telah dijual oleh wali si anak harus di kembali, maka dari itu Balai Harta Peninggalan berhak mencabut wewenang dan memecat wali dari si pewaris tersebut karena telah melanggar aturan dan melalaikan tugasnya sebagai wali. ${ }^{13}$ Balai Harta Peninggalan dalam hal perwalian pengawas itu diperintahkan kepadanya. Wali pengawas wajib memaksa kepada wali atas ancaman kerugian dimana wali diberikan hukuman mengganti biaya kerugian yang dilakukannya. Dalam pasal $418 \mathrm{KUH}$ Perdata yang berisikan. "Balai Harta Peninggalan dan dewan-dewan perwakilan tidak boleh dikesampingkan dari segala campur tangan yang diperintahkan kepada mereka dalam ketentuan Undang-undang" dikatakan senjata pamungkas Balai Harta Peninggalan ketika maju dipersidangan untuk menjaga dan melindungi hak waris anak.

Mengenai kaitannya dengan hak hibah untuk anak dibawah umur dengan obyek sebidang tanah hendaknya dilakukan pendaftaran peralihan hak di kantor pertanahan setempat yang tentunya pengurusannya dilakukan oleh kekuasaan orang tuanya, sehingga setelah terbit sertifikat maka akan muncul nama anak dibawah umur tersebut dalam sertifikat. Ini harus dilakukan dalam rangka perlindungan hukum kepada penerima hak yang masih dibawah umur.

Adapun undang-undang no.23/2002 tentang Perlindungan anak. Pada tahun 2002, pemerintah mengundangkan undang-undang no.23/2002 tentang perlindungan anak. Adapun yang dimaksud dengan perlindungan anak adalah segala kegiatan untuk menjamin dan melindungi anak dan hak-haknya agar dapat hidup, tumbuh, berkembang dan berpartisispasi secara optimal sesuai dengan harkat dan martabat kemanusiaan serta mendapat perlindungan dari kekerasan dan diskriminasi.

Dalam undang-undang perlindungan anak ini diatur juga antara lain mengenai perwalian dan wali pengawas. Pasal 33 UU No.23/2002 menentukan bahwa: Dalam hal orang tua tidak cakap melakukan perbuatan hukum, tidak diketahui tempat tinggal atau keberadaanya, maka seseorang atau badan hukum yang memenuhi persyaratan dapat ditunjuk wali anak yang bersangkutan. Pengangkatan wali dilakukan melalui penetapan pengadilan. Wali wajib mengelola harta milik anak.

Dalam pasal 34 UU No.23/2002 menentukan bahwa: "wali yang ditunjuk berdasarkan penetapan pengadilan dapat mewakili anak untuk melakukan perbuatan hukum, baik didalam maupun diluar pengadilan untuk kepentingan yang terbaik bagi anak"

${ }^{31}$ Dikutip dari dokumen Balai Harta Peninggalan Makassar. Tanggal 27 Juni 2016. 
Dalam hal ini anak belum mendapat penetapan pengadilan mengenai wali, maka harta kekayaan tersebut dapat diurus oleh Balai Harta Peninggalan. Balai Harta Peninggalan bertindak sebagai wali pengawas untuk mewakili kepentingan anak, pengurusan harta tersebut harus mendapat penetapan.

Ketentuan mengenai perwalian dan wali pengawas itu jelas merupakan ketentuan yang bertumpang tindih, baik dengan ketentuan mengenai perwalian maupun wali pengawas yang diatur dalam KUHPerdata dan ketentuan mengenai Balai Harta Peninggalan, maupun dengan ketentuan mengenai perwalian dalam UU No.1/1974 tentang perkawinan ini juga sedikit banyak berpengaruh terhadap tugas-tugas Balai Harta Peninggalan, sebab didalamnya juga diatur mengenai perwalian, yaitu pada bab XI mulai pasal 50 sampai dengan pasal 54.

Keberadaan Balai Harta Peninggalan bermanfaat bagi kepentingan seluruh warga Negara Indonesia, lebih-lebih jika diingatkan bahwa banyak tugas dari Balai Harta Peninggalan bersangkutan dengan kepentingan umum dan bahkan dengan kepentingan Negara semisal masalah perwalian dan wali pengawas, jadi kinerja Balai Harta Peninggalan masih perlu ditingkatkan agar apa yang diharapkan diatas dapat terlaksana dengan lancar, baik dari sudut sarana, prasarananya maupun dari sumber daya manusianya dan ketentuan-ketentuan hukum yang menjadi landasan kerjanya maupun anggaran pembiayaannya.

Adapun kebijakan operasional tugas pokok Balai Harta Peninggalan dapat diperinci sebagai berikut:

1. Mengampu

Kewajiban wali pengawas adalah mewakili kepentingan-kepentingan anak yang belum dewasa, untuk itu Balai Harta Peninggalan boleh memaksa wali membuat inventaris atau pemerincian barang-barang harta peninggalan dalam segala warisan yang jatuh pada si anak yang belum dewasa, menurut hukum perwalian ada tiga macam yaitu: perwalian oleh suami istri hidup lebih lama dengan demikian berarti orang tua yang terlama hidup dengan sendirinya menjadi wali, perwalian yang ditunjuk oleh bapak atau ibu dengan surat wasiat atau akta tersendiri, perwalian diangkat oleh Hakim. Wali-wali ini harus menunaikan perwaliannya yang dipercayakan kepadanya dengan baik dan tulus hati, wali-wali ini juga berkewajiban memberitahukan kepada Balai Harta Peninggalan sebagai wali pengawas tentang perwalian tersebut dan apabila mereka lalai maka boleh dipecat sebagai wali. Balai Harta Peninggalan juga dapat sebagai pengampu apabila orang tua laki-laki meninggal, sang ibu pada saat itu sedang mengandung dan kalau anak itu kemudian lahir maka sang ibu dengan sendirinya (menurut hukum) menjadi wali dan Balai Harta Peninggalan menjadi wali pengawas.

Tugas Balai Harta Peninggalan tercantum dalam ayat terakhir pasal 359 KUHPerdata yang bersangkut paut dengan perwalian dan pengawas wali yang diangkat ditetapkan oleh Hakim atas permohonan yang diajukan oleh keluarga terdekat si anak tersebut. Sementara penetapan pengangkatan wali dari pengadilan Negeri belum ada maka kemungkinan sekali keadaan sudah mendesak agar diadakan tindakan seperlunya demi kepentingan anak yang belum dewasa tersebut, dalam keadaan demikian apabila dipandang perlu Balai Harta Peninggalan mengadakan tindakan-tindakan seperlunya guna mengurus diri dan harta kekayaan anak, tindakan-tindakan tersebut antara lain mengadakan inventerisasi atas harta kekayaan si anak serta mewakili anak tersebut dalam suatu tindakan hukum. Tugas Balai Harta Peninggalan sebagai pengurus atas diri dan harta kekayaan anak belum dewasa akan berakhir ketika wali untuknya telah 
diangkat atau ditetapkan oleh Pengadilan Negeri dengan diangkatnya seorang wali maka tugas Balai Harta Peninggalan selanjutnya berubah menjadi wali pengawas.

Tugas Balai Harta Peninggalan sebagai pengawas wali diatur dalam pasal 366 KUHPerdata yang menyebutkan "dalam tiap-tiap perwalian yang diperintahkan di Indonesia, Balai Harta Peninggalan berkewajiban melakukan tugas wali pengawas." Adapun tugas sebagai wali pengawas, Balai Harta Peninggalan bertindak untuk mengamat-amati apakah wali melaksanakan kewajiban dengan baik atau tidak dan seberapa perlu memberikan nasihat-nasihat kepada wali untuk melakukan kewajibannya dengan sebaik-baiknya, kewajiban wali yang harus diperhatikan oleh Balai Harta Peninggalan antara lain:

a. Dalam tenggang waktu 3 bulan setelah terjadinya kematian menyelenggarakan pendaftaran harta kekayaan suami atau istri (Pasal 127 KUHPerdata).

b. Apabila wali lalai untuk melaksanakan tugasnya tersebut, maka wali pengawas dapat memaksakan agar pendaftaran itu dilakukan (Pasal 370 ayat 2 KUHPerdata).

c. Menyelenggarakan pengurusan harta kekayaan anak dibawah umur itu dengan baik sesuai dengan yang telah ditentukan oleh undang-undang (Pasal 371 KUHPerdata).

d. Tiap tahun wali berkewajiban memberikan perhitungan dan tanggung jawab atas pengurusan yang sudah dilakukan (Pasal 372 jo. 409 KUHPerdata).

e. Apabila wali enggan melaksanakan kewajibannya maka wali dapat digantikan. Berkaitan dengan kewajiban-kewajiban wali tersebut diatas, maka BHP mempunyai kewajiban:

1) Meminta kepada wali untuk menyelenggarakan pendaftaran harta kekayaan yang didalamnya berkepentingan anak belum dewasa.

2) Mewakili kepentingan anak belum dewasa, apabila kepentingan mereka bertentangan dengan kepentingan walinya.

3) Apabila diperlukan memaksakan kepada wali untuk membuat pendaftaran harta kekayaan yang dimaksud.

4) Meminta kepada wali untuk menyediakan jaminan secukupnya.

5) Meminta perhitungan dan tanggung jawab dari wali.

6) Mengajukan usul kepada Pengadilan Negeri untuk memecat wali dan mengajukan calon wali yang baru.

7) Memberikan keterangan kepada Hakim tentang bermanfaat tidaknya penjualan barang yang didalamnya berkepentingan anak belum dewasa.

8) Mewakili anak belum dewasa melakukan perjanjian sewa menyewa apabila penyewanya adalah wali sendiri.

9) Memberikan kuasa kepada wali untuk bertindak sebagai penggugat maupun tergugat dalam perkara perdata guna kepentingan anak belum dewasa.

10) Menghadiri acara pemisahan dan pembagian harta kekayaan yang didalammya berkepentingan anak belum dewasa.

Dari uraian kewajiban wali dan wali pengawas tersebut diatas, dapat disimpulkan bahwa lembaga perwalian dan wali pengawas diadakan oleh perundang-undangan demi kepentingan anak belum dewasa itu sendiri, sehingga hak-hak si anak tidak dilanggar.

Tugas pokok Balai Harta Peninggalan sebagai pengampu atas anak yang masih dalam kandungan, karena manusia merupakan pengembang hak dan kewajiban, dimulai sejak lahir sampai meninggalnya yang bersangkutan. Namun ada kalanya seorang anak yang masih dalam kandungan ibunya dianggap sebagai telah dilahirkan, jika kepentingan anak tersebut menghendaki demikian (Pasal 2 KUHPerdata) ketentuan Pasal 2 KUHPerdata berkaitan erat dengan ketentuan Pasal 348 KUHPerdata yang isinya 
mewajibkan seorang istri yang ditinggal mati oleh suaminya untuk melaporkan kepada Balai Harta Peninggalan ketika suaminya meninggal dan isteri sementara mengandung. Apabila si isteri tersebut berada dalam keadaan hamil maka dengan sendirinya Balai Harta Peninggalan akan bertindak sebagai pengampu atas anak dalam kandungan, sebagai pengampu maka Balai Harta Peninggalan berkewajiban:

1) Membuat berita acara kehamilan

2) Melakukan sesuatu guna melindungi kepentingan anak dalam kandungan tersebut anatara lain melakukan inventarisasi atas harta warisan yang ditinggalkan suaminya dan melayani gugat atau menggugat yang kemungkinan timbul dalam warisan yang dimaksud.

Tugas Balai Harta Peninggalan sebagai pengampu anak dalam kandungan akan berakhir ketika anak tersebut dilahirkan. Kelahiran tersebut ada dua kemungkinan yang lahir hidup atau lahir mati. Kalau seandainya anak tersebut lahir mati, maka warisan yang seharusnya akan diterima anak tersebut beralih dengan sendirinya kepada ahli waris yang lain. Sedangkan kalau anak tersebut lahir hidup, maka tugas Balai Harta Peninggalan selanjutnya berubah menjadi wali pengawas.

Adapun data dari jumlah perwalian yang terjadi dari tahun ke tahun dapat dilihat dalam table sebagai berikut:

Tabel 1

Data perwalian Tahun 2014-2016

\begin{tabular}{|l|c|c|c|c|}
\hline 1 & Tahun & 2014 & 2015 & 2016 \\
\hline 2 & Jumlah perwalian & 1 & 1 & 1 \\
\hline \multicolumn{2}{|c|}{ Jumlah } & & 3 & \\
\hline
\end{tabular}

Berdasarkan data tersebut dapat diketahui bahwa angka perwalian mulai dari tahun 2014-2016 dengan jumlah 3 orang yang telah ditangani oleh Balai Harta Peninggalan Makassar.

\section{Tanggung Jawab Wali Atas Pengurusan Harta Anak}

Pada intinya perwalian adalah pengawasan atas orang sebagaimana diatur dalam undang-undang dan pengelola barang-barang dari anak yang belum dewasa (pupil). ${ }^{14}$ Demikian juga dengan penguasaan dan perlindungan terhadap terhadap seseorang sebagai wali, orang tersebut mempunyai hubungan dengan orang yang dikuasai dan dilindungi, anak atau orang lain selain orang tua yang telah disahkan oleh hukum untuk bertindak sebagai wali, oleh karena itu perwalian tersebut adalah suatu kewanangan yang diberikan kepada seseorang untuk melakukan suatu perbuatan hukum sebagai wakil untuk kepentingan dan atas nama anak yang tidak mempunyai orang tua.

Pasal 50, 51, 52, 53, 54 Undang-Undang Nomor 1 tahun 1974 tentang perkawinan. Pasal 107-112 Kompilasi Hukum Islam (KHI) yang mengatur tentang perwalian dapat disimpulkan bahwa perwalian didefinisikan sebagai kewenangan untuk melaksanakan perbuatan hukum demi kepentingan atau atas nama anak yang orang tuanya telah

${ }^{14}$ Vollmar, Pengantar Studi Hukum Perdata, (Jakarta: Raja Wali Pers, 1997), h. 150. 
meninggal dunia. ${ }^{15}$ Sementara itu perwalian dalam pengertian fiqh Islam terbagi tiga, yaitu:

1. Perwalian terhadap jiwa (al-walayah 'alan-nafs).

2. Perwalian terhadap harta (al-walayah 'alal-mal).

3. Perwalian terhadap jiwa dan harta (al-walayah 'alan nafsi wal-mali ma'an).

Urutan perwalian tersebut merupakan urutan-urutan yang dapat ditunjuk oleh hakim pengadilan agama untuk menjadi wali bagi seorang anak, apabila orang tua si anak sebelum meninggal dunia tidak menunjuk wali untuk anaknya. Penunjukan tersebut diambil dari salah seorang diantara mereka mulai dari kerabat terdekat menurut garis keturunannya.

Wali memiliki tanggung jawab yang bertujuan untuk memelihara akan kesejahteraan dari pada yang diperwalikan, termasuk dalam pemeliharaan harta benda yang dipertinggalkan. Hal in sebagaimana dinyatakan dalam pasal $110 \mathrm{KHI}$, yaitu:

1. Wali wajib mengurus diri dan harta orang yang berada di bawah perwaliannya dengan sebaik-baiknya dan berkewajiban memberikan bimbingan agama, pendidikan dan keterampilan lainnya untuk masa depan si anak.

2. Wali dilarang mengikat, membebani dan mengasingkan harta orang yang berada dibawah perwaliannya, kecuali bila perbuatan tersebut menguntungkan orang yang berada dibawah perwaliannya.

3. Wali bertanggung jawab terhadap harta barang yang berada dibawah perwaliannya dan mengganti kerugian yang timbul akibat kesalahan dan kelalaiannya.

4. Dengan tidak mengurangi ketentuan yang diataur dalam pasal 51 ayat (4) UndangUndang Nomor 1 tahun 1974, pertanggujawaban wali tersebut ayat (3) harus dibuktikan dengan pembukuan yang ditutup tiap tahun sekali.

Menurut KUHPerdata, perwalian terhadap anak dilakukan baik itu secara perorangan maupun yayasan atau lembaga lainnya, ini merupakan akibat dari adanya kebutuhan yang menghendaki adanya perwalian yang ditunjuk oleh pengadilan berdasarkan ketentuan hukum. Sedangkan arti dari perwalian itu sendiri adalah penguasaan terhadap pribadi dan pengurus harta kekayaan seorang anak yang belum dewasa. Dengan demikian anak yang orang tuanya telah meninggal dunia, berada dibawah perwalian.

Pada awal penetapan perwalian, diperlukan upaya inventarisasi semua asset (harta) dari anak dibawah umur tersebut dan wali wajib mendokumentasikan semua perubahan terhadap aset tersebut. Harta tersebut harus diaudit secara annual (tahunan) untuk mengetahui nilai dari asset anak yang diperwlikan itu dan untuk memastikan bahwa hartanya tetap terjaga. Selain itu wali dilarang menjual, mengalihkan, mengadaikan asset anak perwalian. Kemudian jika dalam keadaan terpaksa menjual harta milik anak, maka seorang wali wajib terlebih dahulu memperoleh izin dari pengadilan agama. Sementara proses pengalihan asset, seorang wali diharuskan untuk mengalihkan semua harta kepada anak dibawah perwalian ketika anak telah berusia 21 tahun atau telah menikah. ${ }^{16}$ Namun jika ditemukan adanya harta yang hilang atau disalah gunakan oleh wali, maka pengadilan agama dapat memutuskan perkara tersebut, didasarkan pada proses verifikasi dan inventarisis harta yang dikelola oleh wali jika ditemukan adanya penyalahgunaan, maka wali harus mengganti kerugian tersebut.

\footnotetext{
${ }^{15}$ Bahder Johan Nasution, Hukum Perdata Islam, (Bandung: Mandar Maju, 1997), h. 45-46.

${ }^{16}$ Pasal 111 Ayat (1) Kompilasi Hukum Islam.
} 


\section{KESIMPULAN}

Berdasarkan pembahasan diatas, penulis mengambil kesimpulan:

1. Balai Harta Peninggalan dapat dikemukakan bahwa tugas pokok Balai Harta Peninggalan dalam kasus penanganan anak adalah mengawasi pembagian harta anak selaku wali sementara dan wali pengawas dalam perwalian, mengurus harta si anak agar tetap terlindungi dan untuk memenuhi kebutuhannya.

2. Hukum kewarisan menurut hukum islam sebagai salah satu bagian dari hukum kekeluargaan sangat penting dipelajari agar supaya dalam pelaksanaan pembagian harta warisan tidak terjadi kesalahan dan dapat dilaksanakan dengan seadil-adilnya, sebab dengan mempelajari hukum kewarisan islam dapat terhindar dari dosa yakni tidak memakan harta yang bukan haknya. Maka dalam kasus penanganan kewarisan anak ini sudah sejalan atau tidak bertentangan dengan hukum Islam. 


\section{DAFTAR PUSTAKA}

A. Rahman, Asymuni Dkk. Ilmu Fiqh. Cet. I; Jakarta: Direktorat Jenderal Pembinaan Kelembagaan Agama Islam, 1986.

Anshori, Abdul, Ghofur. Hukum Kewarisan Islam Di Indonesia. Cet. I; Yogyakarta: Gadjah Mada University Press, 2012.

Ashidueqy, Teungku Muhammad Hasbi. Fiqih Muwarris. Semarang: Pustaka Putra, 1999.

Ash-Shabuni, Muhammad Ali. Pembagian Waris Menurut Islam. Jakarta: Gema Insane Press, 1996.

Doi I A. Rahman. Hudud dan Kewarisan. Jakarta: PT. Raja Grafindo Persada, 1996.

Gunawan, Imam. Metode Penelitian Kualitatif. Cet. I; Jakarta: Bumi Aksara, 2013.

Istiqamah. Hukum Waris Dan Benda. Makassar: Alauddin University Press, 2012.

Kementerian Agama. Al-Qur'an Terjemahan dan Tafsir. Bandung: Syaamil Quran, 2011.

Kementerian Pendidikan dan Kebudayaan, Kamus Besar Bahasa Indonesia untuk pelajar. Jakarta Timur: Balai Pustaka, 2011.

Khalifah, Muhammad Thoha Abu Eka. Hukum Waris. Bandung: Tiga Serangkai, 2007.

Khalik, Subehan. Wasiat Kepada Ahli Waris "Telaah Fikih Dengan Pendekatan Kritik Kesahihan Hadis". Makassar: Alauddin University Press, 2013.

Mardani. Hukum Kewarisan Islam Di Indonesia. Cet. II; Jakarta: PT Raja Grafindo Persada, 2015.

Nasution, Bahder Johan. Hukum Perdata Islam. Bandung: Mandar Maju, 1997.

Prasetyo, Teguh. Kriminalisasi Dalam Hukum Pidana. Cet. III; Bandung: Penerbit Nusa Media, 2013.

Rachmad, Budiono. Pembaharuan Hukum Islam di Indonesia. Bandung: PT. Citra Aditya Bakti, 1999.

Saebani, Beni Ahmad. Fiqh Mawaris. Cet. I: Bandung: Pustaka Setia, 2009.

Salihima, Syamsulbahri. Perkembangan Pemikiran Pembagian Warisan Dalam Hukum Islam Dan Implementasinya Pada Pengadilan Agama. Jakarata: Prenadamedia Group, 2015.

Sulistiani, Siska Lis. Kedudukan Hukum Anak Hasil Perkawinan Beda Agama Menurut Hukum Positif Dan Hukum Islam. Cet. I; Bandung: PT Refika Aditama, 2015.

Sutrisno, Hadi. Metode Penelitian. Yogyakarta: Pustaka Pelajar, 1986.

Sofyan Syahril, Beberapa Dasar Teknik Pembuatan Akta (Khusus Warisan). Medan: Pustaka Bangsa Press, 2010.

Syarifuddin, Amir. Hukum Kewarisan Islam. Jakarta: Prenada Media, 2004.

Tutik, Titik Triwulan. Pengantar Hukum Perdata Di Indonesia. Cet. I; Jakarta: Prestasi Pustaka, 2006.

Vollmar, Pengantar Studi Hukum Perdata. Jakarta: Rajawali Pers, 1997.

Yunus, Assaad. Pokok-Pokok Hukum Kewarisan Islam. Jakarta: PT. Alqushwa, 1992. 